УДК 541.122: 538.214

\title{
Magnetic Behavior and Nexafs-spectroscopy of $\mathrm{Bi}_{2} \mathrm{BaNb}_{2-2 x} \mathrm{Co}_{2 x} \mathrm{O}_{9-\delta}$
}

\author{
Lubov V. Rychkova* \\ Pitirim Sorokin Syktyvkar State University \\ Oktyabrskiy prospect, 55, Syktyvkar, 167001 \\ Russia \\ Sergey V. Nekipelov ${ }^{\dagger}$ \\ Pitirim Sorokin Syktyvkar State University \\ Oktyabrskiy prospect, 55, Syktyvkar, 167001 \\ Institute of Physics and Mathematics of the Komi Science Center UB RAS \\ Oplesnina, 4, Syktyvkar, 167982 \\ Russia \\ Boris A. Makeev M $^{\ddagger}$ \\ Institute of Geology of the Komi Scientific Center UB RAS, \\ Pervomayskaya, 54, Syktyvkar, 167982 \\ Russia \\ Vladimir A. Belyy ${ }^{\S}$ \\ Institute of Chemistry of the Komi Scientific Center UB RAS \\ Pervomayskaya, 48, Syktyvkar, 167982 \\ Russia \\ Dmitriy S. Beznosikov \\ Nadezhda A. Zhuk \\ Pitirim Sorokin Syktyvkar State University \\ Oktyabrskiy prospect, 55, Syktyvkar, 167001 \\ Russia
}

\begin{abstract}
Received 09.04.2019, received in revised form 13.09.2019, accepted 25.09.2019
The samples of solid solutions of $\mathrm{Bi}_{2} \mathrm{BaNb}_{2-2 x} \mathrm{Co}_{2 x} \mathrm{O}_{9-\delta}$ composition at $x \leqslant 0.04$ were synthesized by the solid-phase method. The electron state and the nature of the exchange interactions of cobalt atoms in the samples were studied by the measurements of magnetic susceptibility and NEXAFS-spectroscopy. The NEXAFS spectra of the solid solutions and the cobalt oxides $\mathrm{CoO}, \mathrm{Co}_{3} \mathrm{O}_{4}$ were recorded. According to the data of X-ray spectroscopy and magnetic susceptibility, the charge states of cobalt atoms in the solid solutions were identified as $C o(I I)$ and Co(III) in the forms of monomers and exchange-bound aggregates with the antiferromagnetic type of exchange.
\end{abstract}

Keywords: cobalt, clusters, exchange interactions, NEXAFS-spectroscopy.

DOI: 10.17516/1997-1397-2019-12-6-687-693.

\footnotetext{
*lyu-ba24@mail.ru

${ }^{\dagger}$ nekipelovsv@mail.ru

${ }^{\ddagger}$ makboris@mail.ru

§skeyling@yandex.ru

ฯuvn71p3@gmail.com

"nzhuck@mail.ru

(c) Siberian Federal University. All rights reserved
} 


\section{Introduction}

The bismuth-containing layered perovskite-like oxides with structure of the Aurivillius phases draw the interest of researchers due to the discovery of their ferroelectric properties [1]. Particular attention was paid to a thorough analysis of structure and structural features, to technologies of synthesis of nanoscale materials and to the search for new compounds of this type. Studies related to the effect of dopants on the physicochemical properties of these compounds are also very relevant [2-4]. Crystal structure of complex oxides of this type is described by the general formula $\mathrm{A}_{m-1} \mathrm{Bi}_{2} \mathrm{~B}_{m} \mathrm{O}_{3 m+3}$, where the positions $\mathrm{A}$ are occupied by large cations (Bi(III), $\mathrm{Ba}(\mathrm{II}), \mathrm{Pb}(\mathrm{II})$, $\mathrm{Na}(\mathrm{I})$ ), and the positions $\mathrm{B}$ inside the oxygen octahedra are occupied by cations with a smaller radius and a higher charge $(\mathrm{Mo}(\mathrm{VI}), \mathrm{Nb}(\mathrm{V}), \mathrm{Ti}(\mathrm{IV}), \mathrm{Fe}(\mathrm{III}))$. The parameter $\mathrm{m}$ determines the number of the perovskite-like layers of $\left[\mathrm{A}_{m-1} \mathrm{~B}_{m} \mathrm{O}_{3 m+1}\right]^{2-}$ between the layers of $\left[\mathrm{Bi}_{2} \mathrm{O}_{2}\right]^{2+}$, and it has a half-integer or integer values in the range from 1 to 5 [1-4]. In the present paper, the electronic state and the character of interatomic interactions of cobalt atoms in the solid solutions of bismuth barium niobate $\mathrm{Bi}_{2} \mathrm{BaNb}_{2-2 x} \mathrm{Co}_{2 x} \mathrm{O}_{9-\delta}$ were studied using the methods of NEXAFS and magnetic susceptibility. The crystal structure of the bismuth barium niobate was described by the space group A21am $(a=b=0.5567 \mathrm{~nm}$ and $c=2.5634 \mathrm{~nm})$ and was characterized by the alternation of bismuth-oxygen layers with perovskite-like blocks with a thickness of two layers of niobium-oxygen octahedra [5].

\section{Materials and Methods}

The samples of the bismuth barium niobate solid solutions were synthesized by the standard ceramic method from the "special purity grade" bismuth (III), niobium (V) and cobalt (II) oxides by the staged calcination at $650,850,950$ and $1050{ }^{\circ} \mathrm{C}$. The phase composition of the studied samples was controlled by X-ray phase analysis (DRON-4-13, CuK $\alpha$-radiation) and electron scanning microscopy (a scanning electron microscope Tescan MIRA 3LMN, an energy dispersive spectrometer Oxford Instruments x-act), the unit cell parameters of the solid solutions were calculated using the CSD software package [6].

The magnetic susceptibility of the solid solutions was measured by the Faraday method in the temperature interval of $77 \div 400 \mathrm{~K}$ at 16 points of temperatures and magnetic field strengths of $7240,6330,5230$ and 3640 Oe. The accuracy of the measurements was $2 \%$. The samples of cobalt-doped solid solutions were studied by X-ray absorption spectroscopy (NEXAFS - Near Edge X-ray Absorption Fine Structure) using synchrotron radiation at BESSY II (Berlin, Germany). The NEXAFS spectra were obtained by the total electron yield method (TEY).

\section{Results and discussion}

The cobalt containing solid solutions $\mathrm{Bi}_{2} \mathrm{BaNb}_{2-2 x} \mathrm{Co}_{2 x} \mathrm{O}_{9-\delta}$ were synthesized in the concentration range $x \leqslant 0.04$. Electron scanning microscopy and X-ray phase analysis confirmed the single-phase nature of the samples (Fig.1).

The lattice parameters of the dilute solid solutions were almost unchanged and close to the parameters of bismuth barium niobate: $a=0.5540 \mathrm{~nm}, b=2.5621 \mathrm{~nm}, c=0.5535 \mathrm{~nm}$ $\left(\mathrm{Bi}_{2} \mathrm{BaNb}_{1.92} \mathrm{Co}_{0.08} \mathrm{O}_{9-\delta}\right)$, which was associated with the isomorphic replacement of niobium $(\mathrm{V})$ with close in size atoms of cobalt with the charge states of $\mathrm{Co}(\mathrm{II})$ and $\mathrm{Co}(\mathrm{III})$ [7]. The micrographs of the samples with higher content of the dopant $(x=0.06)$ showed inclusions of cobalt (II) that 
were unevenly distributed in the material. It should be noted that the concentration range of the cobalt-doped solid solutions is more narrow than that of iron-doped solid solutions [8,9], which may be due to the lower degree of covalence of the cobalt-oxygen bond compared to the iron-oxygen bond.

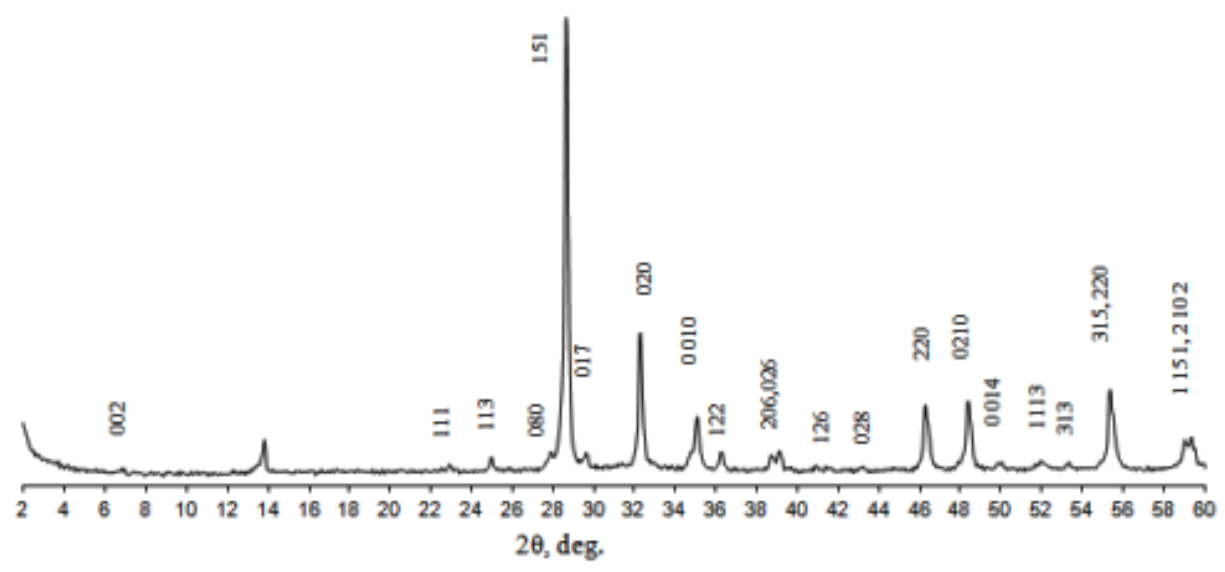

Fig. 1. X-Ray pattern for $\mathrm{Bi}_{2} \mathrm{BaNb}_{1.92} \mathrm{Co}_{0.08} \mathrm{O}_{4-\delta}$

The nature of exchange interactions and the electronic state of cobalt atoms in solid solutions of bismuth barium niobate were studied via magnetic susceptibility measurements in the samples of triclinic and orthorhombic modifications. The results of the measurements allowed us to calculate the paramagnetic components of the magnetic susceptibility $\left[\chi^{\text {para }}(\mathrm{Co})\right]($ Fig. 2$)$ and the values of effective magnetic moments $\left[\mu_{e f f}(\mathrm{Co})\right]($ Fig. 3$)$ of cobalt atoms at various temperatures and concentrations of the solid solutions. The diamagnetic corrections for the calculation of the paramagnetic component of the magnetic susceptibility were introduced taking into account the susceptibility of bismuth barium niobate measured in the same temperature range.

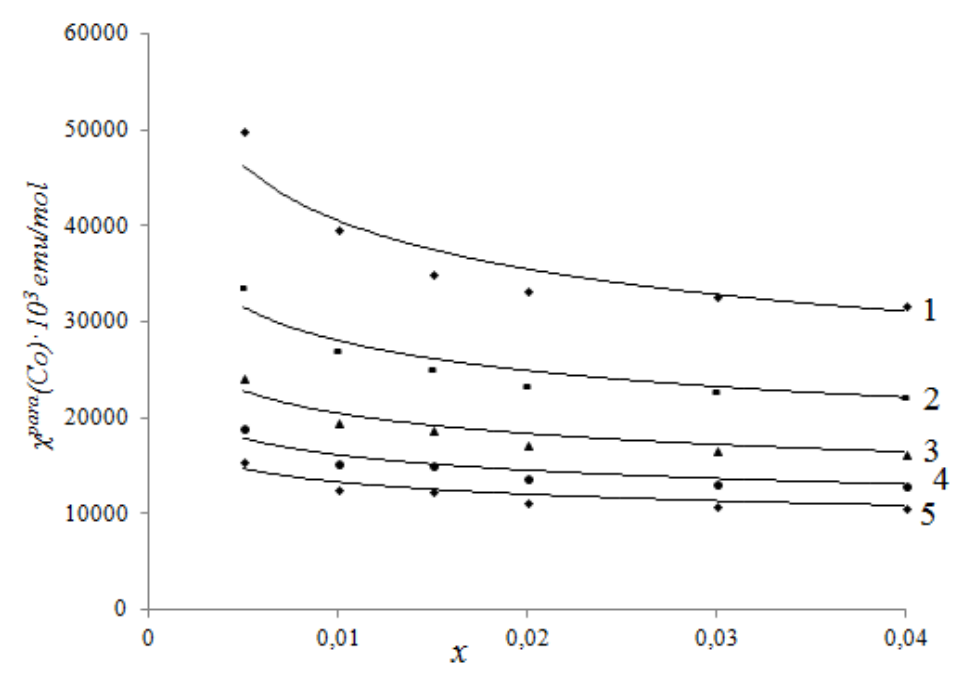

Fig. 2. Paramagnetic component isotherms of the magnetic susceptibility of cobalt in the solid solutions of $\mathrm{Bi}_{2} \mathrm{BaNb}_{1.92} \mathrm{Co}_{0.08} \mathrm{O}_{4-\delta}$ at 90 (1), 140 (2), 200 (3) and $320 \mathrm{~K}$ (4) 


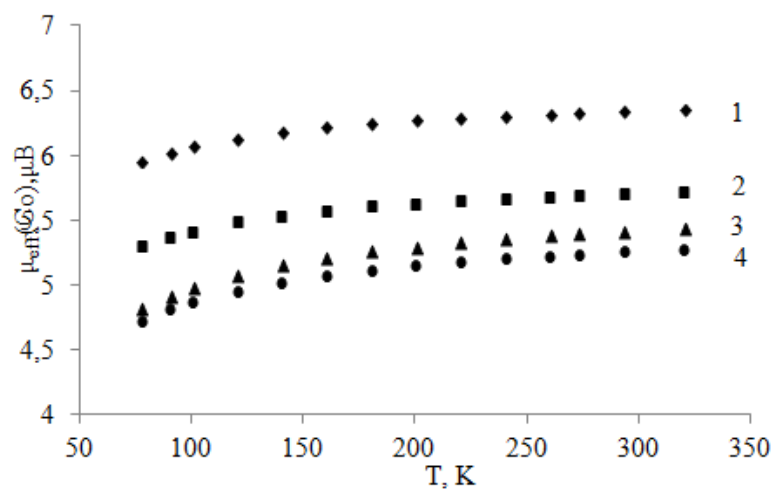

Fig. 3. Temperature dependencies of the effective magnetic moment of cobalt in the solid solutions of $\mathrm{Bi}_{2} \mathrm{BaNb}_{1.92} \mathrm{Co}_{0.08} \mathrm{O}_{4-\delta}$ at x 0.005 (1), 0.010 (2), 0.02 (3), 0.04 (4)

It was established that the dependence of the reciprocal paramagnetic component of the magnetic susceptibility per one mole of cobalt atoms on temperature obeys the Curie-Weiss law in all of the solid solutions in the studied temperature range. The negative values of the Weiss constant revealed the antiferromagnetic exchange interactions. The isotherms of the paramagnetic component of the magnetic susceptibility of cobalt atoms $\left[\chi^{\text {para }}(\mathrm{Co})\right]$ in the solid solutions were a characteristic of dilute antiferromagnets. The magnitude of the effective magnetic moment of cobalt atoms calculated by the extrapolation of the concentration dependences of $\left[\chi^{\text {para }}(\mathrm{Co})\right]$ to infinite dilution of solid solutions increased with increasing temperature from $\mu_{e f f}(\mathrm{Co})=6.29$ $\mu_{B}(90 \mathrm{~K})$ to $6.79 \mu_{B}(260 \mathrm{~K})$ and exceeded the pure spin values of the magnetic moments of high-spin cobalt atoms $\operatorname{Co}(\mathrm{II})\left(\mu_{e f f}=3.89 \mu_{B}\right)$ and $\operatorname{Co}(\mathrm{III})\left(\mu_{e f f}=4.92 \mu_{B}\right)$ [10]. The observed fact indicated the aggregation of paramagnetic cobalt atoms in the infinitely dilute solid solutions with the formation of clusters mainly with the antiferromagnetic type of exchange. The decrease in the paramagnetic component of the magnetic susceptibility of cobalt atoms with an increase in the concentration of solid solutions was associated with the predominance of antiferromagnetic interactions between cobalt atoms or their clusters. This assumption was also supported by the temperature dependences of the effective magnetic moment of cobalt atoms on the concentration of the solid solutions (Fig. 3).

The antiferromagnetic exchange usually occurs between isovalent atoms of cobalt (II) and (III) in the same spin state, e.g. $\mathrm{Co}(\mathrm{III})_{s=2}-\mathrm{Co}(\mathrm{III})_{s=2}$ or $\mathrm{Co}(\mathrm{II})_{s=3 / 2}-\mathrm{Co}(\mathrm{II})_{s=3 / 2}$ through the exchange channels $d_{x^{2}-y^{2}}\left\|p_{x}\right\| d_{x^{2}-y^{2}}, d_{x^{2}-y^{2}}\left\|p_{y}\right\| d_{x^{2}-y^{2}}, d_{x y}\left|p_{y}\right| d_{x y}$ and $d_{x z}\left|p_{z}\right| d_{x z}$. On the contrary, the ferromagnetic exchange is realized between cobalt atoms in equal oxidation states with different valences or different spines. No evidences of this type of exchange was observed in the solid solutions of bismuth barium niobate.

The charge state of cobalt atoms in the samples of $\mathrm{Bi}_{2} \mathrm{BaNb}_{2-2 x} \mathrm{Co}_{2 x} \mathrm{O}_{9-\delta}$ solid solutions was studied using NEXAFS spectroscopy at the synchrotron radiation source BESSY-II. The NEXAFS spectra were recorded in the total electron yield (TEY) mode [11]. Fig. 4 shows the absorption spectra of cobalt atoms in $\mathrm{Bi}_{2} \mathrm{BaNb}_{2} \mathrm{O}_{9}$ and in oxides $\mathrm{Co}_{3} \mathrm{O}_{4}$ and $\mathrm{CoO}$ [12]. As can be seen, the spectra of cobalt in bismuth barium niobate are most similar in intensity and energy position of the major peaks to the $\mathrm{Co} 2 \mathrm{p}_{3 / 2}$-spectrum of $\mathrm{CoO}$ and to a lesser extent to the spectra of $\mathrm{Co}_{3} \mathrm{O}_{4}$. The cobalt atoms in $\mathrm{CoO}$ are divalent, i.e. they have a charge state of $\mathrm{Co}^{2+}$, while in the mixed oxide, $\mathrm{Co}_{3} \mathrm{O}_{4}$, cobalt atoms are present in the oxidation states (II) and (III). Meanwhile, the ratio of intensities of the bands at $781 \mathrm{eV}$ and $779 \div 780 \mathrm{eV}$ in the broadband spectrum of cobalt in bismuth niobate allowed us to process this spectrum as a superposition 
of subspectra of cobalt in oxidation states (II) and (III) with a lower content last one. The oxidation states (III) of cobalt atoms is not unexpected, as shown earlier for the solid solutions of heterovalent substitution of bismuth niobate $[13,14]$. This was associated with the stabilizing effect of the structure of solid solutions.

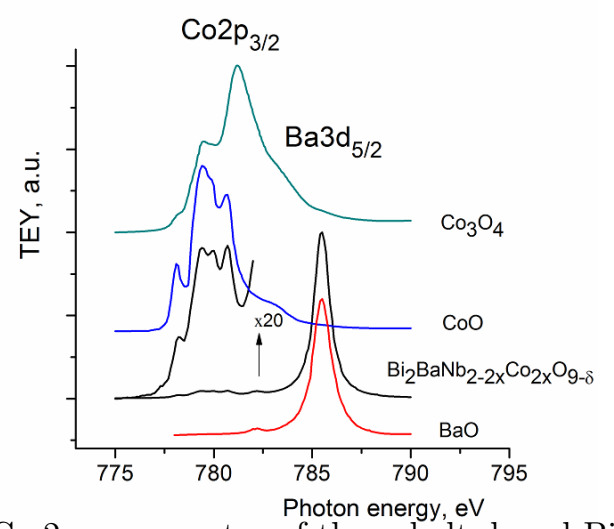

Fig. 4. NEXAFS Co $2 \mathrm{p}_{3 / 2}$ - spectra of the cobalt-doped $\mathrm{Bi}_{2} \mathrm{BaNb}_{1.92} \mathrm{Co}_{0.08} \mathrm{O}_{4-\delta}$

\section{Conclusion}

The cobalt-doped solid solutions of bismuth barium orthoniobate were synthesized by the solid phase method in a narrow concentration range $(x \leqslant 0.04)$. The higher content of cobalt led to appearance of cobalt (II) oxide. According to the study of magnetic susceptibility, it was found that the infinitely dilute solid solutions contained $\mathrm{Co}$ (II) and $\mathrm{Co}$ (III) high-spin atoms and their aggregates with the antiferromagnetic type of exchange. The proportion of the aggregates increased with increasing cobalt concentration. According to NEXAFS spectroscopy, cobalt atoms in the solid solutions exhibited the charge states Co(III) and, mainly, Co(II).

\section{References}

[1] G.A.Smolensky, Physics of ferroelectric phenomena, Leningrad, Nauka,, 1985 (in Russian).

[2] G.A.Geguzina, A.T.Shuvaev, E.T.Shuvaeva, V.G.Vlasenko, Synthesis and Structure of New Phases of the $\mathrm{A}_{m-1} \mathrm{Bi}_{2} \mathrm{~B}_{m} \mathrm{O}_{3 m+3}(m=2)$ Type, Cristallograph. Rep., 50(2005), 59-64.

[3] V.A.Isupov, Crystal chemical aspects of the bismuth-containing layered compounds of the $\mathrm{A}_{m-1} \mathrm{Bi}_{2} \mathrm{~B}_{m} \mathrm{O}_{3 m+3}$ type., Ferroelectrics., 189(1996), 211-227.

[4] R.Macquart, B.J.Kennedy, T.Kamiyama, F.Izumi, Structural phase transitions in the ferroelectric oxides $\mathrm{Ba}_{1-x} \mathrm{~Pb}_{x} \mathrm{Bi}_{2} \mathrm{Nb}_{2} \mathrm{O}_{9}(\mathrm{x}=0.375,0.625)$, J. Phys.-Condes. Matter., 16(2004), $5443-5452$.

[5] Ismunandar, B.J.Kennedy, Gunawan, Marsongkohadi, Structure of $\mathrm{ABi}_{2} \mathrm{Nb}_{2} \mathrm{O}_{9}(\mathrm{~A}=\mathrm{Sr}$, Ba): Refinement of Powder Neutron Diffraction Data, J. Solid State Chem., 126(1996), $135-141$.

[6] L.G.Akselrud, Yu.N.Grin, P.Yu.Zavalij, et al., CSD-universal program package for single crystal or powder structure data treatment, Thes. Rep. XII Eur. Crystallographic. Meet., 3(1985), 155. 
[7] R.D.Shannon, Revised effective ionic radii and systematic studies of interatomic distances in halides and chalcogenides., Acta Crystallogr. A, 32(1976), 751-767.

[8] N.A.Zhuk, N.V.Chezhina, V.A.Belyy et al., Magnetic susceptibility of solid solutions $\mathrm{Bi}_{2} \mathrm{SrNb}_{2-2 x} \mathrm{Fe}_{2 x} \mathrm{O}_{9-\delta}$., J. Magn. Magn. Mater., 451(2018), 96-101.

[9] N.A.Zhuk, N.V.Chezhina, Belyy et al., Influence of barium and strontium atoms on magnetic properties of iron-containing solid solutions $\mathrm{Bi}_{2} \mathrm{MNb}_{2} \mathrm{O}_{9}$ (M - Ba, Sr), J. Magn. Magn. Mater., 469(2019), 574-579.

[10] V.T.Kalinnikov, Yu.V.Rakitin, Introduction to Magnetochemistry. Method of Static Magnetic Susceptibility in Chemistry., J. Phys.: Condens. Matter., Nauka, Moscow, 1980 (in Russian).

[11] J.Stohr, NEXAFS Spectroscopy, Springer, Berlin, 1992.

[12] T.J.Regan, Ohldag H., Stamm C. et al. Chemical effects at metal/oxide interfaces studied by x-ray-absorption spectroscopy, Phys. Rev. B, 64(2001), 214422.

[13] N.V.Chezhina, N.A.Zhuk, Structure, magnetic, and electrical properties of bismuth niobates doped with d-elements: XII. Magnetic behavior of $\mathrm{Bi}_{3} \mathrm{Nb}_{1-x} \mathrm{Mn}_{x} \mathrm{O}_{7-\delta}$ solid solutions, Russ. J. Gen. Chem., 85(2015), 2520-2524.

[14] Z N.A.huk, V.A.Belyy, V.P.Lutoev et al., Mn doped $\mathrm{BiNbO}_{4}$ ceramics: Thermal stability, phase transitions, magnetic properties, NEXAFS and ESR spectroscopy, Alloy compd., 778(2019), 418-426.

\section{Магнитное поведение и NEXAFS-спектроскопия $\mathrm{Bi}_{2} \mathrm{BaNb}_{2-2 x} \mathrm{Co}_{2 x} \mathrm{O}_{9-\delta}$}

Любовь В. Рычкова

Сыктывкарский государственный университет им. Питирима Сорокина Октябрьский пр-т, 55, Сыктывкар, 167001

Россия

Сергей В. Некипелов

Сыктывкарский государственный университет им. Питирима Сорокина Октябрьский пр-т, 55, Сыктывкар, 167001 Физико-математический институт Коми НЦ УрО РАН

Оплеснина, 4, Сыктывкар, 167982

Россия

Борис А. Макеев

Институт геологии Коми научного центра УрО РАН

Первомайская, 54, Сыктывкар, 167982

$$
\text { Россия }
$$

Владимир А. Белый

Институт химии Коми научного центра УрО РАН

Первомайская, 48, Сыктывкар, 167982

Россия

Дмитрий С. Безносиков

Надежда А. Жук

Сыктывкарский государственный университет им. Питирима Сорокина

Октябрьский пр-т, 55, Сыктывкар, 167001

Россия 
Твердобазным методом синтеза получены образцы твердых растворов состава $\mathrm{Bi}_{2} \mathrm{BaNb}_{2-2 x} \mathrm{Co}_{2 x} \mathrm{O}_{9-\delta}$ в ограниченном концентрачионном интервале $(x \leqslant 0.04)$. Методами магнитной восприимчиости и NEXAFS-спектроскопии исследовано электронное состояние и характер обменных взаимодействий атомов кобальта в образцах. Получены NEXAFS-спектры твердых растворов и оксидов кобальта СоO, $\mathrm{Co}_{3} \mathrm{O}_{4}$. По данным рентгеновской спектроскопии и магнитной восприимчивости, атомы кобальта в твердых растворах находятся в зарядовом состоянии Со(II) и Со(III) в форме мономеров и обменносвязанных агрегатов $c$ антиферромагнитным типом обмена.

Ключевые слова: кобальт, кластеры, обменные взаимодействия, NEXAFS-спектроскопия. 